\title{
Rancangan ruang bermain anak yang kreatif dan edukatif dengan pemanfaatan lahan fasilitas umum
}

\author{
Irnawati Siregar*, Zelmi Sriyolja \\ Program Studi Arsitektur, Fakultas Teknik dan Perencanaan, Universitas Ekasakti, Padang \\ *Koresponden E-mail: siregar.irna68@gmail.com
}

(Diterima 24 Februari 2020|Disetujui 17 Juni 2020|Diterbitkan 30 Juli 2020)

\begin{abstract}
The purpose of this study is to plan creative and educative children's play spaces, and to introduce social life at an early age. The problem in this study is that there is no playing environment for children under five and elementary school age, so that it affects the play patterns and creativity of children in their neighborhoods. Children are far from social life, tend to play games using electronic and virtual media. This research method is a qualitative descriptive method, employing surveys in research locations, interviews, observation of children's behavior, and playing patterns. The results of this study are in the form of creative and educative children's play planning by designing play spaces that can interact socially with children of different ages and businesses, as well as revive traditional games of regions that are almost extinct.
\end{abstract}

\section{Keywords: environmental planning, playroom, creative, educative playroom, public facilities land}

Permukiman adalah bagian dari lingkungan hidup di luar kawasan lindung, baik yang berupa kawasan perkotaaan maupun pedesaan yang berfungsi sebagai lingkungan tempat tinggal atau lingkungan hunian dan tempat kegiatan yang mendukung peri kehidupan dan penghidupan (Permen PU No 32 Tahun 2006).

Menurut SNI 03-1733-2004 apabila jumlah penduduk minimum 2.500 jiwa pada wilayah permukiman sudah seharusnya ada sebuah tempat bermain. Arena yang dilayani menurut SNI berkisar antara $1,04 \quad \% \quad-2 \%$ dari jumlah penduduk permukiman, dengan radius pencapaian ke ruang bemain yaitu antara 200m - 500m (Ishak, et al., 2018). Sementara jumlah penduduk yang ada di delapan RW yang jadi target penelitian berjumlah 4997, sudah melebihi pedoman perencanaan lingkungan pemukiman perkotaan SNI 03-1733-2004. Sudah selayaknya ada ruang bermain untuk anak, berdasarkan radius yang ditentukan SNI tersebut. Perencanaan ruang bermain terletak di lokasi RW 11 tepatnya RT 03 kelurahan Kubu Dalam Parakah Karakah, dengan luas lokasi site adalah $740 \mathrm{~m} 2$.

Berdasarkan data survey dan pengamatan di lapangan dari seluruh wilayah permukiman yang ada di kelurahan Kubu Dalam Parak karakah, dari delapan RW yang jadi target penelitian yang berdekatan lokasinya kawasannya, tidak di temui adanya ruang bermain bagi anak, hal tersebut berdampak kepada pola bermain anak. Permainan yang dilakukan anakanak setelah sore hari, setelah pulang sekolah dan harihari libur, anak-anak cendrung bermain sepeda, bermain bola, berkejaran di jalanan dan depan-depan rumah warga, serta di sepanjang jalan dan gang-gang permukiman. Terkadang warga atau pemilik yang lahan atau halaman rumahnya dipakai oleh anak-anak untuk bermain, merasa keberatan dan meminta anakanak untuk pindah tempat main dengan alasan berisik.

Survey dan pengamatan yang dilakukan juga menemukan, anak-anak cendrung untuk bermain di jalanan dan di depan-depan rumah masyarakat seperti yang di tunjukkan oleh oleh Gambar 2, dimana anakanak dari RW 11 bermain ke RW 12 dengan melintas di jalan raya Parak Karakah, atau sebaliknya anak dari RW 12 bermain ke RW 11. Situasi tersebut sangat membahayakan bagi anak-anak karena renta terhadap kecelakaan.

Bagi sebagian orang tua yang tidak mengizinkan anaknya untuk bermain di jalanan dan di depan rumah warga, anak-anak tersebut diberi kebebasan bermain di dalam rumah dengan mengundang teman-teman sebayanya untuk melakukan permainan yang tidak mengganggu orang lain, berupa permainan dengan melakukan kegiatan yang bersifat ruang tertutup dalam video game, youtube dan menonton televisi.

Anak adalah aset dan investasi bangsa di masa depan. Kualitas sumber daya manusia sebagai indikator utama keberhasilan suatu bangsa dalam melakukan pembangunan yang di mulai sejak dini perlu perhatikan (Widywati, 2007). Melihat situasi dengan tidak adanya ruang bermain bagi anak dapat berdampak kepada tumbuh kembangnya seperti anak dapat bersifat individualis, berperilaku tertutup, mementingkan diri sendiri, yang mengakibatkan anak memiliki interaksi yang rendah terhadap orang-orang yang ada disekitarnya. Melalui bermain anak memperoleh kesempatan dan pengalaman yang dapat merangsang proses perkembangannya dari aspek: nilai agama dan moral, kognitif, fisik-motorik, bahasa, sosial dan emosional, serta seni dan kreativitas (Eliasa, 1988).

Undang-undang Nomor 35 Tahun 2014 yang merupakan perubahan atas Undang-Undang Nomor 23 Tahun 2002 mengamanatkan bahwa Negara, Pemerintah dan Pemerintah daerah berkewajiban dan bertanggung jawab memberikan dukungan sarana prasarana dan ketersediaan sumberdaya manusia dalam penyelenggaraan perlindungan anak. Salah satunya melalui penyediaan sarana dan prasarana Ruang Bermain Ramah Anak. 
Sejalan dengan Undang-Undang Nomor 35 Tahun 2014, Kementrian Pemberdayaan Perempuan dan Perlindungan Anak (PPPA) pada siaran Pers Nomor: B-240/Set/Rokum/MP 01/10/2019 menyatakan bahwa Negara hadir untuk melindungi hak anak diantaranya mengupayakan pemenuhan hak anak untuk bermain melalui penyediaan Ruang Bermain Ramah Anak (RBRA) serta hak anak atas pengasuhan keluarga dan lingkungan tumbuh kembang anak (kemen pppa, 2019).

Berdasarkan Undang-undang Nomor 35 Tahun 2014 dan pernyataan Kementrian Pemberdayaan Perempuan dan Perlindungan Anak (PPPA) pada siaran Pers Nomor: B-240/Set/Rokum/MP 01/10/2019, dengan jumlah penduduk 11.780 jiwa di kelurahan Kubu Dalam Parak Karakah sudah selayaknya permukiman di kelurahan Kubu Dalam Parak Karakah memiliki ruang bermain untuk anak. Taman bermain anak banyak jenisnya diantaranya: permainan fisik, permainan kreatif, permainan social, permainan indra dan permainan dalam ketenangan (Baskara, 2011).

\section{BAHAN DAN METODE}

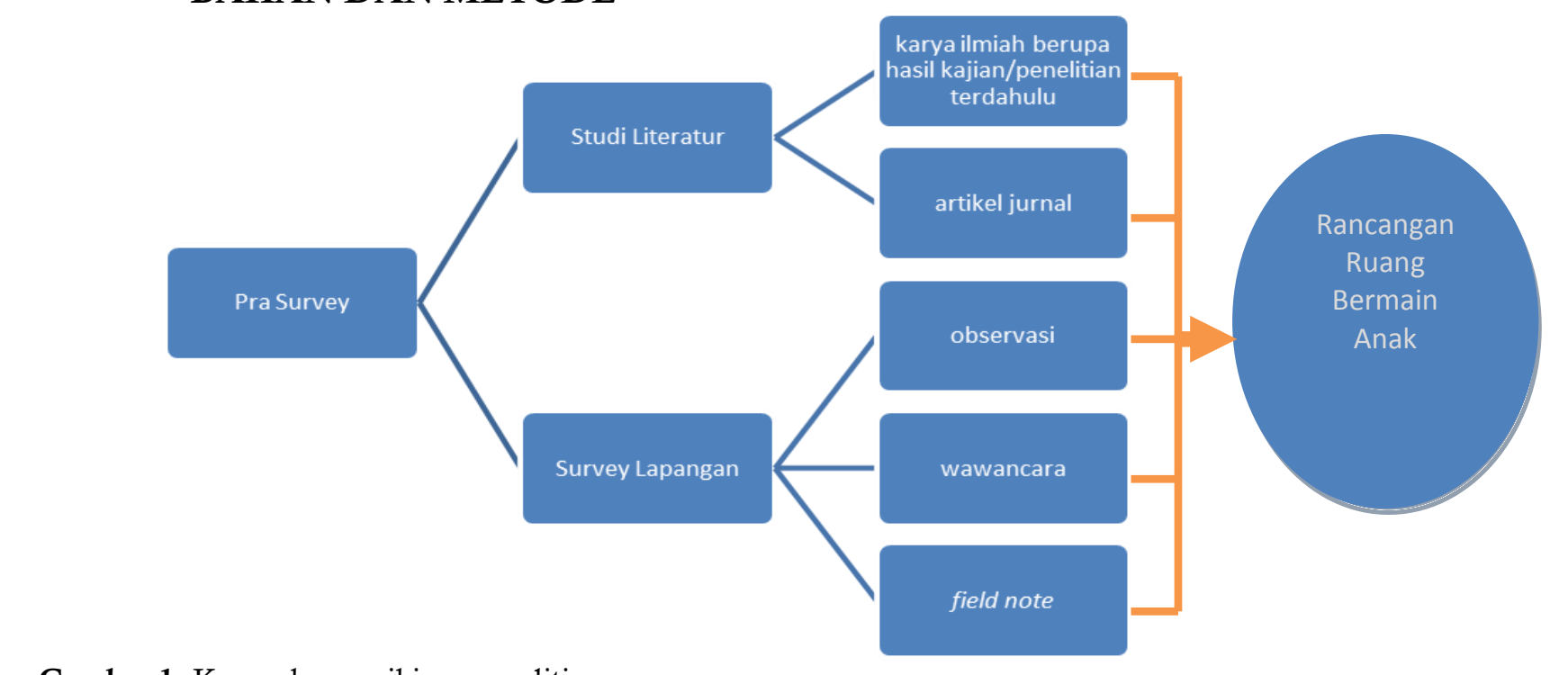

Penelitian ini termasuk pada penelitian deskriptif kualitatif, pada penelitian ini dilakukan pengamatan terhadap anak-anak yang sedang bermain dalam rentang waktu antara jam pulang sekolah dari jam 10.30 pagi- sampai dengan jam 18.00 sore. Lokasi penelitian terfokus pada lingkungan di delapan RW, yaitu mulai dari RW 06 sampai dengan RW 13, dimana kedelapan RW tersebut saling berdekatan. Sesuai dengan standar SNI bahwa batas dari radius capaian keruang bermain anak dengan jarak antara $200 \mathrm{~m}$ - 500m. Pengamatan terhadap anak saat bermain menurut Widyawati (2015), termasuk kepada mengdeskripsikan dan menginterpretatif data dari awal, mengkonstruksi data yang diperoleh dari sumber data.

Teknik pengumpulan data dilakukan dengan analisis kepustakaan melalui text book, karya ilmiah berupa hasil kajian/penelitian terdahulu, artikel jurnal, gambar-gambar permukiman yang sesuai dengan standar SNI. Untuk analisis lapangan dilakukan dengan observasi, wawancara, field note. Sedangkan untuk metoda perancangan ruang bermain mengacu kepada desain ruang bemain anak pada permukiman penduduk dengan standar Ruang Bermain Ramah Anak (RBRA).

Gambar 1. Kerangka pemikiran penelitian

Menurut (Groat \& Wang dalam S. P. Martana, 2006) teknik pengumpulan data dapat dilakukan dengan mempergunakan beberapa teknik pendekatan, antara lain: untuk observasi pengamatan langsung kelokasi permukiman yang jadi target penelitian, teknik ini dilakukan dengan dokumentasi foto, rekam video, menggambar /sketsa. Sedangkan untuk wawancara yaitu mengadakan tanya jawab kepada beberapa informan baik masyarakat, lembaga non formal maupun pihak instansi pemerintah, wawancara dilakukan dengan membuat daftar pertanyaan atau kuestioner. Sedangkan unutk field note dilakukan dengan mencatat keseluruhan hal-hal yang ditemukan dilapangan, baik data informan/responden, karekteristik kawasan permukiman, sosial budaya, dan hal-hal yang dirasa perlu untuk data penelitian.

\section{HASIL DAN PEMBAHASAN}

Hasil pengolahan data yang didapat dilapangan pada umumnya di permukiman yang menjadi target penelitian, setuju dibangun ruang bermain anak yang kreatif dan edukatif. Adanya ruang bermain anak ini akan mengantisipasi terjadinya kecelakaan dan cidera terhadap anak, sekaligus meminimalisir kecanduan anak terhadap game online, youtuber, dan menonton televisi yang tidak mendidik. Hasil wawancara yang 
dilakukan kepada masyarakat, $85 \%$ masyarakat setuju di bangun ruang bermain ini.

Menurut SNI 03-1733-2004 apabila jumlah penduduk minimum 2.500 jiwa pada wilayah permukiman sudah seharusnya ada sebuah tempat bermain. Arena yang dilayani menurut SNI berkisar antara $1,04 \% \quad-2 \%$ dari jumlah penduduk permukiman, dengan radius pencapaian ke ruang bemain yaitu antara $200 \mathrm{~m}-500 \mathrm{~m}$ (Imrianti, Rahmi, Ishak. 2018). Sementara jumlah penduduk yang ada di delapan RW yang jadi target penelitian berjumlah 4997, sudah melebihi pedoman perencanaan lingkungan pemukiman perkotaan SNI 03-1733-2004. Sudah selayaknya ada ruang bermain untuk anak, berdasarkan radius yang ditentukan SNI tersebut. Perencanaan ruang bermain terletak di lokasi RW 11 tepatnya RT 03 kelurahan Kubu Dalam Parakah Karakah, dengan luas lokasi site adalah $740 \mathrm{~m} 2$.

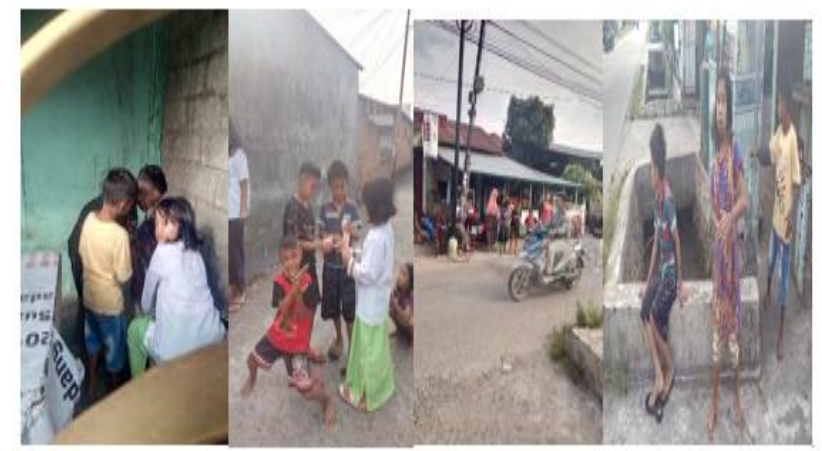

Gambar 2. Suasana Lingkungan Tempat Anak Bermain RW 11 dan RW 12

Bentuk permainan yang di buat pada ruang bemain anak di permukiman penduduk di lingkungan RW 11, mengacu kepada Ruang Bermain Ramah Anak (RBRA), dimana semua elemen-elemen yang pada ruang bermain dibuat dengan tidak membahayakan anak dan ramah lingkungan (Ishak. 2018).

Metoda perancangan diperlukan pendataan ke
lokasi perencanaan dengan menidentifikasi
penempatan perencanaan yang sesuai dengan tata ruang dalam permukiman. Menganalisis dan mengidentifikasi jenis-jenis permainan anak yang ada di lapangan untuk didesain sesuai dengan kebiasaan anak dalam bermain, serta jenis pealatan yang dipakai dalam bermain (Hutapea, 2015).

Salah satu bentuk permainan yang akan di buat adalah bentuk permainan kreatif yang sesuai dengan kebiasaan anak-anak di permukiman tempat dilakukannya penelitian yakni permainan bola kaki, bola kasti, petak umpat, ayunan, jungkat jungkit, seluncuran, terowongan, gelantungan, area lukis, zig zag ban bekas, dan bermacam permainan yang dapat dilakukan tanpa menyiapkan medianya, seperti: main tali, gundu, kelereng, gasing, ging gong, pantak lele, conglak, dan lain sebagainya.

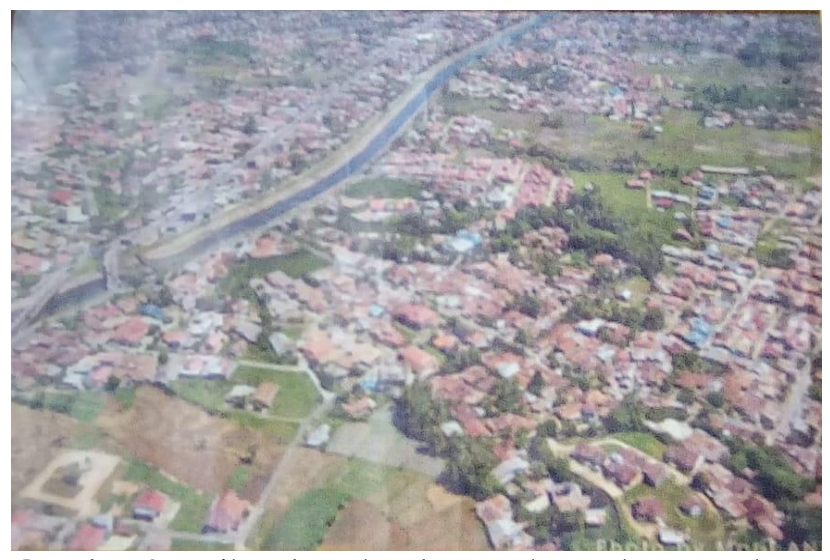

Gambar 3. Wilayah Kelurahan Kubu Dalam Parak Karakah

Bentuk permainan Edukatif yang di rencanakan mengandung nilai pendidikan yang berfungsi untuk merangsang daya imajinasi anak dalam proses perkembangan kongnitif, proses kegiatannya yaitu pemberian stimulasi sehingga dapat meningkatkan aspek perkembangan dalam proses tumbuh kembang anak yang dinilai dari perkembangan motorik kasar, motorik halus, kemampuan bicara dan bahasa serta kemampuan sosisalisasi dan kemandirian (Ishak, 2018). Hal yang sama juga di ungkapkan oleh Sagarih (2012) bahwa bermain sangat erat kaitannya dengan pengembangan fisik anak.

Wadah untuk permainan Edukatif yang direncanakan berupa gedung serbaguna yang dapat menampung krativitas anak-anak dalam bidang seni, budaya, dan pemantapan nili-nilai agama.

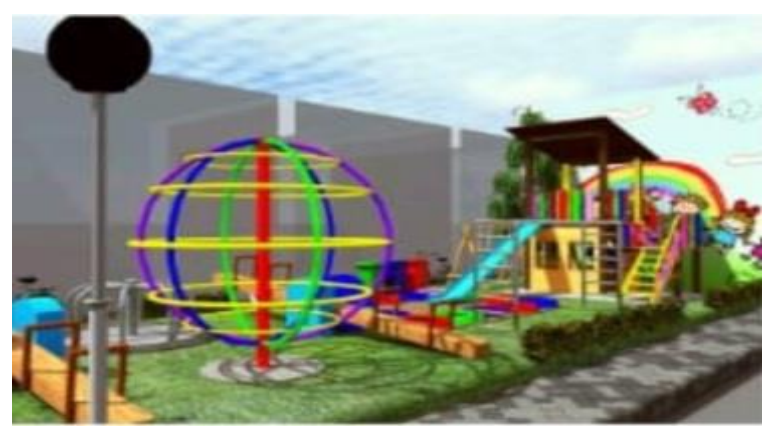

Gambar 4. Standar RuangBermain Ramah Anak (Imrianti, Rahmi, Ishak. 2018)

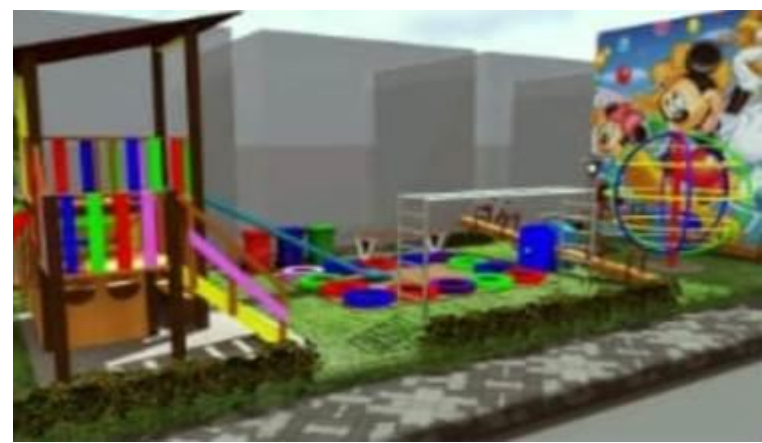

Gambar 5. Standar Ruang ermain Ramah Anak (Imrianti, Rahmi, Ishak. 2018) 


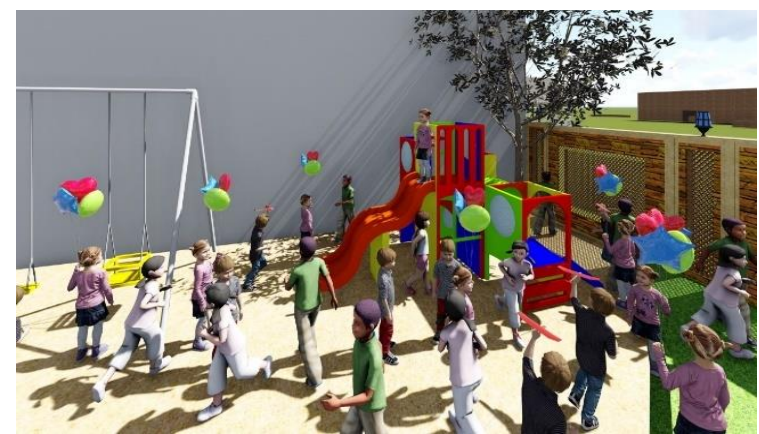

Gambar 6. Suasana Taman Kreatif dan Edukatif Kelurahan Kubu Dalam Parak Karakah

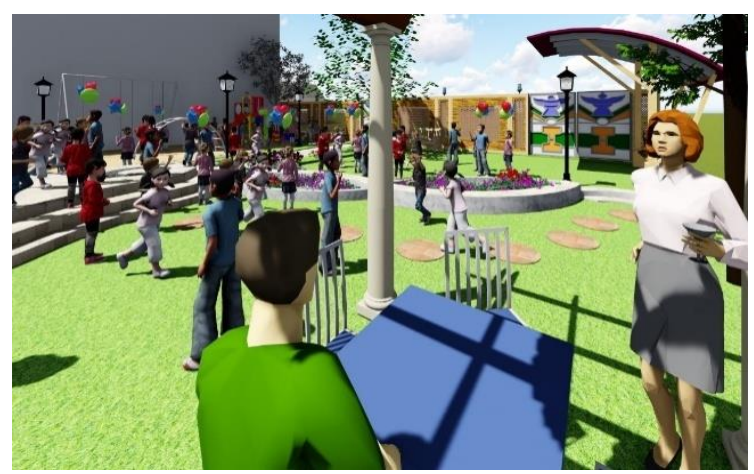

Gambar 7. Suasana Taman Kreatif dan Edukatif Kelurahan Kubu Dalam Parak Karakah

Rancangan ruang bermain kreatif dan edukatif ini sangat bermanfaat bagi anak-anak, karena ruang bermain ini memanfaatkan ruang terbuka sehingga anak-anak bebas untuk bergerak (Ardiyanto, 2017). Mereka lebih bebas melakukan kegiatan berlari, melompat, menendang, dan kegiatan fisik motorik lainnya. Anak dapat melakukan kegiatan yang berkaitan dengan alam, seperti: membuat dekorasi dari daun, ranting atau batu untuk pengenalan warna, bentuk dan tekstur (Elfiadi, 2016).

Kegiatan lain yang dapat dilakukan melihat awan, menikmati angin yang bertiup, bermainan air hujan, dan pengenalan satwa dan tanaman, semua kegiatan tersebut dapat melatih anak untuk lebih peduli dengan lingkungan, sehingga anak mempunyai kesadaran untuk menjaganya seiring dengan tumbuh dewasanya anak. Manfaat lain yang dapat diperoleh dengan bermain di luar ruangan adalah dapat meningkatkan kemampuan intelektualitas, berfikir kritis, dan kreatif.

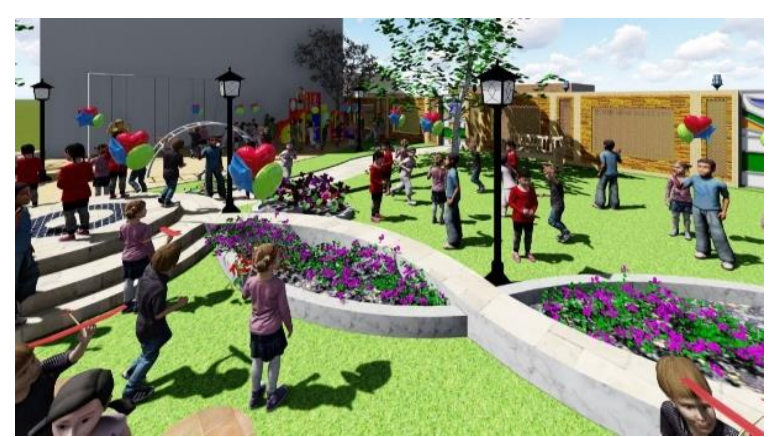

Gambar 8. Taman Kreatif dan Edukatif Kelurahan Kubu Dalam Parak Karakah

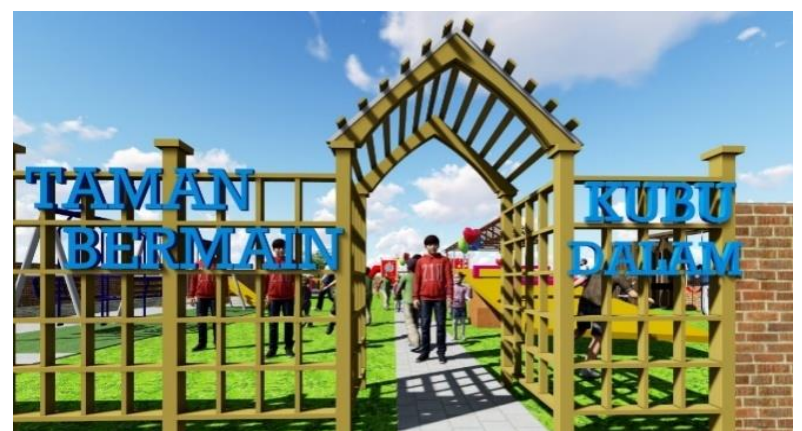

Gambar 9. Taman Kreatif dan Edukatif Kelurahan Kubu Dalam Parak Karakah

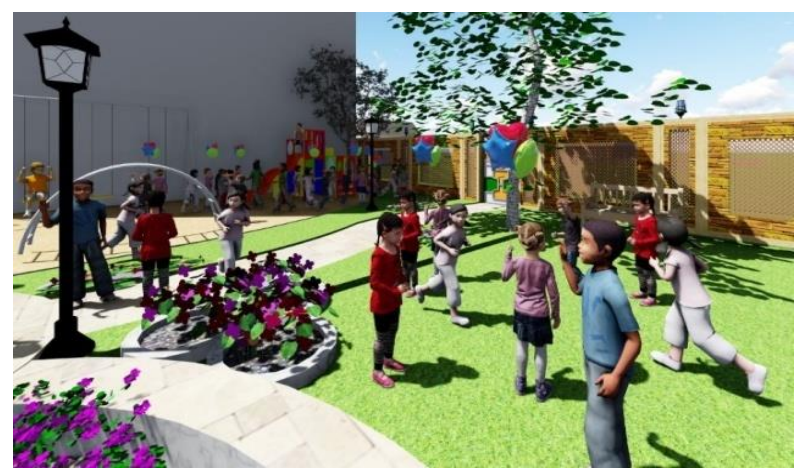

Gambar 10. Taman Kreatif dan Edukatif Kelurahan Kubu Dalam Parak Karakah

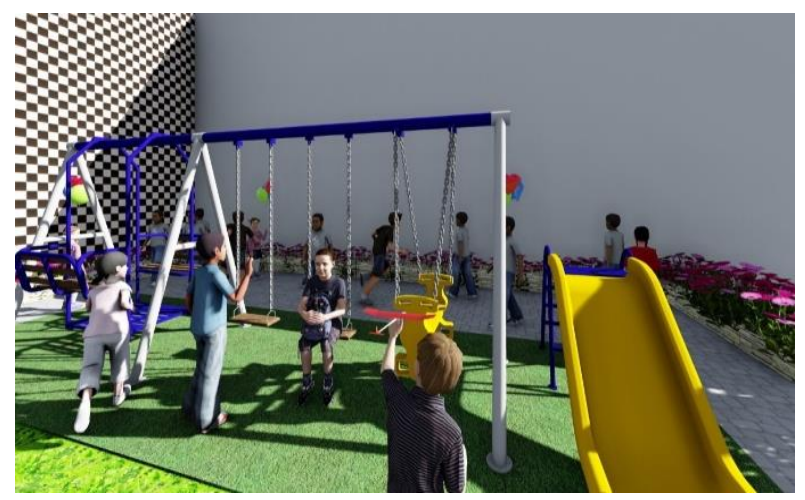

Gambar 11. Taman Kreatif dan Edukatif Kelurahan Kubu Dalam Parak Karakah

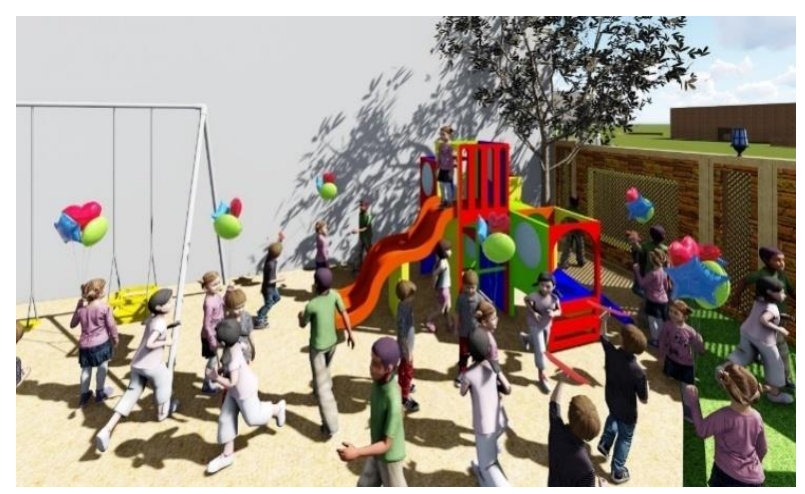

Gambar 12. Taman Kreatif dan Edukatif Kelurahan Kubu Dalam Parak Karakah 


\section{SIMPULAN}

Rancangan pemanfaatan tanah fasum untuk ruang bermain anak kreatif dan edukatif di kelurahan Kubu Dalam Parak Karakah dapat disimpulkan sebagai berikut:

Berdasarkan peta lokasi delapan RW yang jadi target penelitian (RW 06, 07, 08, 09, 10, 11, 12, dan 13) selayaknya ada ruang bermain yang dibutuhkan masyarakat dari ke enam RW tersebut. Hasil survey yang dilakukan kebutuhan lahan fasum berada di lokasi RW 11, dengan luas $740 \mathrm{~m} 2$.

Rancangan yang dilakukan berupa penyediaan fasilitas ruang bermain anak yang kreatif, edukatif dan dapat berkreasi aktif dan tanggap terhadap semua tipe permainan dengan tidak meninggalkan tipe-tipe permainan tradisional yang mampir punah.

\section{UCAPAN TERIMA KASIH}

Ucapan terima kasih kepada ketua LPPM Universitas Ekasakti yang telah memfasilitasi penelitian ini. Selanjutnya kepada pemerintah terkait di lokasi penelitian, pemuka masyarakat dan masyarakat Kelurahan Kubu Dalam Parak Karakah.

\section{DAFTAR PUSTAKA}

Asy'ari, M. Y. (2008) .Peraturan Menteri Negara Perumahan Rakyat RI No. 32/PERMEN/M/2006. Journal of Chemical Information and Modeling, 53(9), 287. https://doi.org/10.1017/CBO9781107415324.004

Ardiyanto, A. (2017). Bermain Sebagai Sarana Pengembangan Kreativitas Anak Usia Dini. Jendela Olahraga, 2(2), 35-39. https://doi.org/10.26877/jo.v2i2.1700

Badan Standardisasi Nasional. (2004). SNI 03-17332004: Tata cara perencanaan lingkungan perumahan.

Baskara, M. (2011). The Principle of Design Control. Lanskap Indonesia, 3(1), 27-34.

Elfiadi. (2016). Bermain dan Permainan Bagi Anak Usia Dini. VII(1), 51-60

Eliasa, E.I. (1988). Pentingnya Bermain Bagi Anak Usia Dini Oleh: Eva Imania Eliasa, M.Pd. Staf Pengajar Program Studi Psikologi Pendidikan dan Bimbingan FIP UNY.

Hutapea, C. R. (2015). Taman Bermain Anak Dengan Penekanan Aspek Keamanan Dan Kenyamanan Di Tarekot Malang. Jurnal Mahasiswa Jurusan Arsitektur, 1(3), 2.

Ishak, R. A., Wikantari, R., \& Amri, N. (2018). Implementasi Perencanaan Ruang Bermain Anak yang Kreatif dan Edukatif di Kelurahan Cambaya Kota Makassar. TEPAT Jurnal Teknologi Terapan Untuk Pengabdian Masyarakat, 1, 169-178.

Martana, M.T. (2006). Problematika Penerapan Metode Field Research Untuk Penelitian Arsitektur Vernakular Di Indonesia. DIMENSI (Jurnal Teknik Arsitektur), 34(1), 59-66. Retrieved from http://puslit2.petra.ac.id/ejournal/index.php/ars/ article/view/16458.

Saragih, J.F.B., (2012). Makna Spasial Bermain Pada Anak yang TInggal di Kawasan Permukiman Padat di Jakarta (Spatial Meaning of Play on Children Living at the Dense Settlement Area in Jakarta). Psychology Applied to Work: An Introduction to Industrial and Organizational Psychology, Tenth Edition Paul, 53(9), 1689-1699. https://doi.org/10.1017/CBO9781107415324.00

Widyawati, V. (2015). Penilaian Ruang Bermain Anak Di Kota Depok," vol. 8, no. 3, pp. 195-207.

UU No 35 Tahun 2014. (2014). Undang-Undang No 35 tahun 2014 Tentang Perlindungan anak. Cell, 3 (4),1-15. ttps://doi.org/10.1016/j.cell.2009.01.043 https://www.kemenpppa.go.id/index.php/page/re ad/29/2364/kemen-pppa-penuhi-hak-bermainanak-melalui-rbra.11 Oktober 2019. 